\title{
A comparative study of the Indonesia and Chinese educative systems concerning the dominant incentives to entrepreneurial spirit (desire for a new venturing) of business school students
}

\author{
Yang Kaijun ${ }^{1 *}$ and Puput Ichwatus Sholihah ${ }^{2}$
}

\footnotetext{
*Correspondence: niceyoung@126. com

${ }^{1}$ Economic and International Trade Hohai University, 8 West Focheng Road, Nanjing Jiangsu 210098 China

Full list of author information is available at the end of the article
}

\begin{abstract}
This study aims to analyze the influence of direct and indirect effect of the theory of planned behavior on entrepreneurial intention by using entrepreneurial education as an intervening variable. The study involved 109 students from Business School of Hohai University in China and 110 students from Business School of Brawijaya University in Indonesia. The data were obtained by using accidental sampling technique. In this case, the sample criteria were students that have taken up courses/ seminars/training on entrepreneurship. Path analysis technique in this research was used by making use of existing software AMOS (Analysis of Moment Structure) version 18.00. The results of this study demonstrate the significance of subjective norm and perceived behavioral control to entrepreneurial education in Chinese students. Furthermore, this study also found indirect effect of perceived behavioral controls on entrepreneurial intention with entrepreneurial education as an intervening variable among Chinese students.

Keywords: Theory of planned behavior; Entrepreneurial education and entrepreneurial intention
\end{abstract}

\section{Background}

With the increase in the number of unemployed intellectuals, Indonesia and China face limited employment opportunities for college graduates. The 2012 report of World Bank shows that unemployment record number in Indonesia amounted to 15.9 million (6.6\%) and amounted to 58,4 million people (4.5\%) in China. Out of the total number of unemployed in Indonesia, 3.1\% are scholars (Sutianto 2012); whereas 8.5\% of the total number of unemployed are scholars in China (Anonim 2013). The current conditions are liable to deteriorate because of global competition situation (eg, the implementation of the AEC for Indonesia and LCAs implementation for China) due to which college graduates from Indonesia and China will have to compete with graduates from universities all around the world. Indonesia and China as two rapidly developing countries of eastern Asia have to solve the problem of unemployment of 'well' educated young people. Scholar and college graduates in Indonesia and China

\section{Springer}

(c) 2015 Kaijun and Ichwatus Sholihah; licensee Springer. This is an Open Access article distributed under the terms of the Creative Commons Attribution License (http://creativecommons.org/licenses/by/4.0), which permits unrestricted use, distribution, and reproduction in any medium, provided the original work is properly credited. 
need appropriate guidance and support so that they are not limited to become job seekers but they also become job creators.

Fostering the entrepreneurial spirit of the college student is believed to be one of the solutions for reducing the level of unemployment. This kind of solution has been widely dealt in the advance countries. Developed countries like North America, UK, Ireland, and some European countries use entrepreneurship education with the aim of fostering entrepreneurial spirit in young people in order to reducing the level of unemployment (Keat et al. 2011). College graduates are expected to become competent and independent young entrepreneurs. The existing number of youth entrepreneurs in Indonesia, which is only about $1.56 \%$ (3.5 million) of the total population. Therefore, Indonesia still needs to create new entrepreneurs. Meanwhile, China even already has $14 \%$ (1.4 billlion) youth entrepreneurs also still need to create new entrepreneurs as well, since China is country with the largest population in the world. Understanding and comparing the characteristic of the factors that can foster entrepreneurship from this two countries is an interesting topic to investigate. University students need to be encouraged and their intentions should be fostered towards entrepreneurship.

Fostering entrepreneurship has become an important topic for current policy makers. It turns out that policy can contribute to boosting the level of entrepreneurship. In 2013, Indonesian government is targeting the addition of five million new entrepreneurs to 2025 by developing human resources for the advancement of national entrepreneurs. Since February 2011 the Indonesian government has issued many policies to support the advancement of entrepreneurship in Indonesia, especially for graduation student. In order to foster the spirit of entrepreneurship, the Indonesian government continues rolling the entrepreneurial empowerment programs. For example: 1000 graduate entrepreneurial programs, Program Kreatif Mahasiswa Kewirausahaan (PKMK), entrepreneurship training programs, and strengthening social assistance, and financing programs through Corporate Social Responsibility. While same like Indonesian government, Chinese government has realized the importance of entrepreneurship. Both the central government and local government at various levels have issued preferential policies, established venture fund for university graduates, set up venture incubation parks, held university student entrepreneurship forum, providing workable environment resources for university graduates to start up and develop business of their own (Yanhong and Yibin 2011).

In some previous research, mentioned that one of the factors the growth of entrepreneurship in a country is based on the role of universities in the implementation of entrepreneurship education (Zimmerer 2002; Kuratko 2005; Sciascia et al. 2004). Entrepreneurship education refers to the pedagogical process involved in the encouragement of entrepreneurial activities behaviors and mindsets (Binks et al. 2006). Entrepreneurship education has a purpose to be able to create and increase awareness to established own business as a career choice among young people (Clayton 1989; Fleming 1996). In order words, purpose of entrepreneurship education is intended to change the mindset of students to have behavior and even intention toward entrepreneurship that ultimately they can create new business which could also create jobs opportunity (Fayolle and Gailly 2005). Thus, universities need to implement teaching methods based concrete empirical input to provide students with meaningful knowledge about entrepreneurship in order to develop entrepreneurship spirit among students (Wu and Wu 2008). 
While Autio et al. (2001); Leon et al. (2007); Wu and Wu (2008), Gelderen et al. (2007) applied the theory of planned behavior to analyze factors influencing entrepreneurial intent among university students. Entrepreneurial intentions have a psychological nature, psychologist have proven that intentions are the best predictor of any planned behavior, particularly when the behavior is rare, hard to observe, or involves unpredictable time lags (Krueger et al. 2000). Since new business ventures are not developed in a day, entrepreneurship could be seen as a type of planned behaviour. In order to understand the behaviour of people, Ajzen (1991) developed the Theory of Planned Behaviour (hereafter TPB; Figure 1). The TPB of Ajzen (1991) helps to understand how we can change the behaviour of people. In the field of entrepreneurship the TPB (Ajzen 1991) has been applied to various studies in the last decades. The TPB turned out to be a starting-point for other models of entrepreneurial intention.

The research in these paper studies two effects, direct effect the TPB and entrepreneurship education to students' entrepreneurial intention in Indonesia and China. On the other hand, this study also measures indirect effect between the TPB to entrepreneurial intention using entrepreneurship education as variable intervening. The purpose of this study was to determine how the TPB and entrepreneurship education in Indonesia and China can explain entrepreneurial intentions of students. In addition, this study also compared the characteristics of how entrepreneurship education can moderate the effect of TPB to entrepreneurial intention in both countries.

\section{Literature review}

\section{Entreprneurial intention}

Krueger and Carsrud (1993) defines entrepreneurial intention as individual commitment to start a new business. While Bird (1988) defines entrepreneurial intention as the level of cognitive awareness which directs the set up of a new business. Bird clarifies that intention is a thinking situation consisting of concentration, experience and individual behavior towards specific objective or certain behavior. It is important to understand the overall process of entrepreneurial intention because intention is usually related in establishing a new business (Bird 1988; Krueger and Carsrud 1993). According to Summer (1998); when a person has certain intentions, he is sure to direct his behavior so that it runs parallel with the objective in achieving the intention.

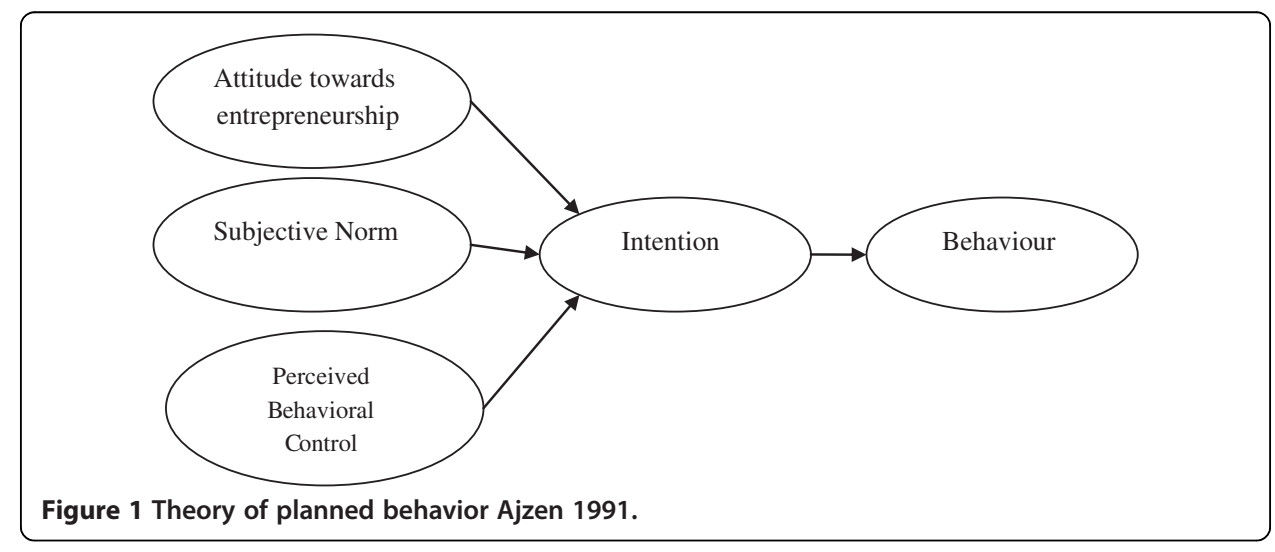


Entrepreneurial intentions lately begun to receive attention for study because it is believed that an intention with regard to the behavior of proven may be a reflection of the actual behavior. In the theory of planned behavior, it is believed that factors such as attitudes and norms will form a person's subjective intentions and will directly affect the behavior (Fishbein \& Ajzen 1985 in Tjahjono \& Ardi 2008). Therefore, understanding of entrepreneurial intention may reflect the tendency of people to establish a business in real terms (Jenkins \& Johnson 1997).

\section{Theory planned of behavior}

Ajzen (1991) developed a psychological model of "Planned Behaviour." It is a theory that may be applied to nearly all voluntary behaviours and it provides quite good results in very diverse fields, including the choice of professional career (Ajzen 2001; Kolvereid 1997). It captures three motivational factors that influence behaviour, which are as follows (Ajzen 1991 in Liñán and Chen 2009):

- Attitude towards the entrepreneurship refers to the level of the individual evaluations in assessing whether being an entrepreneur was favorable (positive) or adverse (negative).

- Subjective norms would measure social pressure to determine whether the behavioral entrepreneurship needs to be done or not. Subjective norms refer to perceptions of relationship in which a group has a profound influence over the behavior of people in it and thus learns where social networks affect individual behavior.

- Perceived behavioural control would be defined as feeling comfortable or unfortable to perform the behavior and is assumed to reflect past experience and anticipated impediments and obstacles.

These three elements would constitute the explanatory variables of intention. Their relative contribution to the configuration of intention is not established in the model, as it may change from case to case.

\section{Entrepreneurship education}

Entrepreneurship education programs related to education and training set the attempts to direct the entrepreneurial behavior or to provide the elements that affect a person's intentions as entrepreneurial knowledge or fosters the desire of entrepreneurship through holding entrepreneurial activity (Selcuk and Turker 2009).

The purpose of entrepreneurship education is associated with developing a variety of skills and attributes such as the ability to think creatively, work in a team and to manage risk. Educational programs on entrepreneurship are in contrast to other educational standards. According to Maguire and Lunati (2009), entrepreneurship education is important to recognize the skills and attitudes that lead to the entrepreneurial nature of the work without binding rules. Some activities included in entrepreneurship education are categorized as such:

1. Skills,

2. Development of personal and social skills, and

3. Skills required for starting a business and financial. 
Basic entrepreneurship education programs are generally targeted at students who are still in college. In a study (Leon and Palaci Descals 2007), social factors consist of several factors that can influence a person's decision to take up a career as an entrepreneur or to take up entrepreneurial education.

Entrepreneurial education has been argued as an effective way to promote and bolster the interest of entrepreneurship among students. Exposures to this knowledge may instil positive attitudes towards entrepreneurship among students (Basu \& Virick 2007). Entrepreneurial education at tertiary level has also become an essential component of many curriculums in private and public higher learning institutions. Since future entrepreneurs can be found amongst those who are currently undergoing their educational process at the universities, entrepreneurship education has been used as one of the most effective ways to promote the transition of graduates into the world of entrepreneurship (Ismail et al. 2009).

\section{Empirical studies}

TPB has been able to explain entrepreneurship intentions in student (Gelderen et al. 2007; Wu and Wu 2008; Leon and Palaci Descals 2007; Kolvereid 1997). There have been many previous studies that describe the relationship between TPB to entrepreneurial intention. Most of the studies using a sample of students (Basu \& Virick 2007; Krueger et al. 2000; Autio et al. 2001; Gelderen et al. 2007).

Autio et al. (2001) applied TPB to analyze factors influencing entrepreneurial intent among university students from Finland, Sweden, the United States and the United Kingdom; they found that attitude, subjective norm and perceived behavioral control had significant effects on intention. Furthermore, they identified perceived behavioral control as the most important determinant of entrepreneurial intent, with subjective norm as the weakest one. Gird and Bagraim (2008) also examined the theoretical sufficiency of TPB. The survey questionnaires were completed by final year commerce students from two universities in the Western Cape, South Africa. A conclusion was reached that TPB significantly explained the entrepreneurial intentions.

In addition, entrepreneur education also has a role in causing student entrepreneurship intentions, this is according to research Wu and Wu (2008) in "The Impact Of Higher Education On Entrepreneurial Intention Of University Student In China". This research's result show that the education factor influenced attitudes toward entrepreneurship. In addition, research Leon and Palaci Descals (2007) and Liñán and Chen (2009) also found entrepreneurial education directly affects entrepreneurial intention. While Karali (2013) in a study entitled "The Impact of Entrepreneurship Education on Entrepreneurial Intentions Programs: An application of the theory of planned behavior" explains that students who participated in entrepreneurship education programs, are more likely to have higher attitude towards entrepreneurship, subjective norm, and greater perceived behavioral control than non-participants. Thus, from the previous studies mentioned above, it can be concluded that there is a relationship in which each of the variables proposed in this study (Table 1).

\section{Conceptual framework}

This study builds on previous studies that have applied TPB and entrepreneurial education entrepreneurship to understand and predict entrepreneurial intention. The conceptual framework is presented in Figure 2 
Table 1 Summary of previous research

\begin{tabular}{|c|c|c|c|}
\hline Title & Sample & Variable & Result \\
\hline $\begin{array}{l}\text { Basu and Virick (2007) } \\
\text { 'assessing entrepreneurial } \\
\text { intentions amongst } \\
\text { students: a comparative } \\
\text { study' }\end{array}$ & $\begin{array}{l}123 \text { students at San } \\
\text { Jose State University }\end{array}$ & $\begin{array}{l}\text { Dependent: entrepreneurial } \\
\text { intention } \\
\text { Independent: education, } \\
\text { parents owned a } \\
\text { business, and work } \\
\text { experience }\end{array}$ & $\begin{array}{l}\text { Variables of education and } \\
\text { family have a positive } \\
\text { relationship with the } \\
\text { attitudes toward } \\
\text { entrepreneurship, subjective } \\
\text { norms, and perceived } \\
\text { behavioral control }\end{array}$ \\
\hline $\begin{array}{l}\text { Krueger et al. (2000) } \\
\text { 'competing models of } \\
\text { entrepreneurial intention' }\end{array}$ & $\begin{array}{l}\text { University students } \\
\text { who were on the } \\
\text { verge of graduation }\end{array}$ & $\begin{array}{l}\text { Dependent: entrepreneurial } \\
\text { intention } \\
\text { Independent: theory of } \\
\text { planned behavior and } \\
\text { entrepreneurial event }\end{array}$ & $\begin{array}{l}\text { This research showed } \\
\text { positive result on both the } \\
\text { theories they examined }\end{array}$ \\
\hline $\begin{array}{l}\text { Autio et al. (2001) } \\
\text { 'entrepreneurial intent } \\
\text { among students in } \\
\text { Scandinavia and in the USA' }\end{array}$ & $\begin{array}{l}\text { University students } \\
\text { from Finland, Sweden, } \\
\text { the United States, and } \\
\text { the United Kingdom }\end{array}$ & $\begin{array}{l}\text { Dependent: entrepreneurial } \\
\text { intention } \\
\text { Independent: theory } \\
\text { planned of behavior }\end{array}$ & $\begin{array}{l}\text { All variables of the theory of } \\
\text { planned behavior had } \\
\text { significant effects on } \\
\text { intention }\end{array}$ \\
\hline $\begin{array}{l}\text { Kolvereid and Isaksen (2006) } \\
\text { 'prediction of employment } \\
\text { status choice intentions' }\end{array}$ & $\begin{array}{l}\text { Norwegian business } \\
\text { founder }\end{array}$ & $\begin{array}{l}\text { Dependent: entrepreneurial } \\
\text { intention } \\
\text { Independent: attitude, } \\
\text { subjective norm, and } \\
\text { self-efficacy construct }\end{array}$ & $\begin{array}{l}\text { Both attitude and subjective } \\
\text { norm over intent to become } \\
\text { self-employed. Self efficacy } \\
\text { did not add to the explanation } \\
\text { of the variance of the } \\
\text { self-employment intention } \\
\text { behavior }\end{array}$ \\
\hline $\begin{array}{l}\text { Gelderen et al. (2007) } \\
\text { 'explaining entrepreneurial } \\
\text { intentions by means of the } \\
\text { theory of planned behavior' }\end{array}$ & $\begin{array}{l}200 \text { students of } \\
\text { business } \\
\text { administration in } \\
\text { Amsterdam }\end{array}$ & $\begin{array}{l}\text { Dependent: entrepreneurial } \\
\text { intention } \\
\text { Independent: theory of } \\
\text { planned behavior }\end{array}$ & $\begin{array}{l}\text { Attitudes toward } \\
\text { entrepreneurship and } \\
\text { perceived behavioral } \\
\text { control have positive } \\
\text { and significant relationship } \\
\text { to entrepreneurial intention }\end{array}$ \\
\hline $\begin{array}{l}\text { Wu and Wu (2008) 'the } \\
\text { impact of higher education } \\
\text { on entrepreneurial intention } \\
\text { of university students in } \\
\text { China' }\end{array}$ & $\begin{array}{l}\text { Students in Tongji } \\
\text { University, China }\end{array}$ & $\begin{array}{l}\text { Dependent: entrepreneurial } \\
\text { intention } \\
\text { Independent: theory of } \\
\text { planned behavior } \\
\text { Antecedent: Education }\end{array}$ & $\begin{array}{l}\text { Education factor influenced } \\
\text { attitude towards } \\
\text { entrepreneurship and } \\
\text { perceived behavioral } \\
\text { control has positive effect } \\
\text { on entrepreneurial intention }\end{array}$ \\
\hline $\begin{array}{l}\text { Gird and Bagraim (2008) } \\
\text { 'the theory of planned } \\
\text { behavior as predictor of } \\
\text { entrepreneurial intent } \\
\text { amongst final-year } \\
\text { university students' }\end{array}$ & $\begin{array}{l}\text { Final-year commerce } \\
\text { students from two } \\
\text { universities in Western } \\
\text { Cape, South Africa }\end{array}$ & $\begin{array}{l}\text { Dependent: entrepreneurial } \\
\text { intention } \\
\text { Independent: theory of } \\
\text { planned behavior }\end{array}$ & $\begin{array}{l}\text { The theory of planned of } \\
\text { behavior significantly } \\
\text { explained the entrepreneurial } \\
\text { intention }\end{array}$ \\
\hline $\begin{array}{l}\text { Liñán and Chen (2009) } \\
\text { 'intention-based models of } \\
\text { entrepreneurship education' }\end{array}$ & $\begin{array}{l}93 \text { students from the } \\
\text { University of Seville } \\
\text { and } 73 \text { students from } \\
\text { the University of Jaen }\end{array}$ & $\begin{array}{l}\text { Qualitative research } \\
\text { which discusses about } \\
\text { entrepreneurship } \\
\text { education, intention } \\
\text { models, and } \\
\text { entrepreneurial intention }\end{array}$ & $\begin{array}{l}\text { Influence of each } \\
\text { entrepreneurship } \\
\text { education's course on } \\
\text { the variables determining } \\
\text { intention is different } \\
\text { depending on the kind } \\
\text { of course considered }\end{array}$ \\
\hline $\begin{array}{l}\text { Sofia Karali (2013) 'the } \\
\text { impact of entrepreneurship } \\
\text { education program on } \\
\text { entrepreneurial intention: an } \\
\text { application of the theory of } \\
\text { planned behavior' }\end{array}$ & $\begin{array}{l}\text { Students from } 11 \\
\text { universities and } 9 \\
\text { universities of applied } \\
\text { science }\end{array}$ & $\begin{array}{l}\text { Dependent: entrepreneurial } \\
\text { intention } \\
\text { Independent: participation } \\
\text { in entrepreneurship } \\
\text { program } \\
\text { Mediator: theory of } \\
\text { planned behavior }\end{array}$ & $\begin{array}{l}\text { Participants in } \\
\text { entrepreneurship education } \\
\text { program are more likely to } \\
\text { intend to start their own } \\
\text { business directly after their } \\
\text { studies compared to } \\
\text { non-participants }\end{array}$ \\
\hline
\end{tabular}




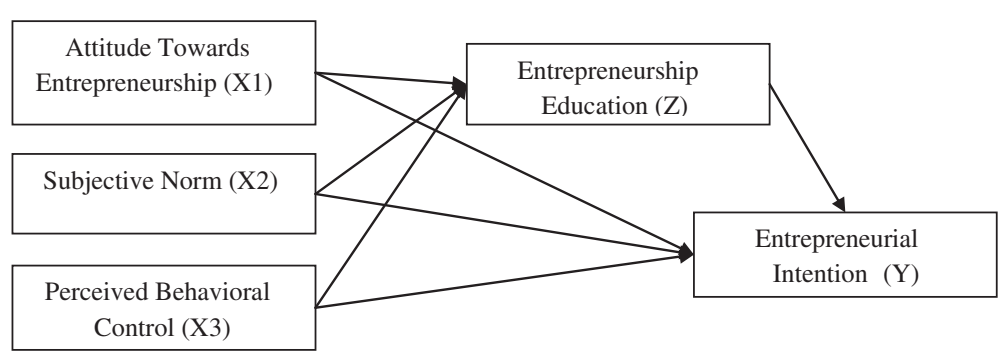

Figure 2 Conceptual framework.

Based on the framework of thought as put down in review literature above, several hypothesis have been formulated which will be tested in this research (Table 2).

\section{Methods}

\section{Population and sampling techniques}

The study of population was carried out on business school students at Brawijaya University, Indonesia and Hohai University, China; which organize regular entrepreneurship courses, seminars, and training. Brawijaya University is university that has a vision to become Entrepreneur University, Economics and Business School is one of the faculty who adopt and implement the vision of the university by providing a variety of programs which can support student entrepreneurship. This program such as: regularly seminars, entrepreneurship week, entrepreneurship training, funds for business proposals of students who are considered worthy, and participation in a business plan competition in both the national and international scale. While Hohai University located in Nanjing Jiangsu well-known business school has been promoting entrepreneurship as a career option. Some programs such as : innovation and entrepreneurship training programs, participation Entrepreneur Challenge Cup, business visits to local companies around china. this all have done by Hohai University in order to facilitate students to be able to understand and choose entrepreneurship as a career option.

Respondents in this study were selected by accidental sampling. In this case, the sample criteria were students that have taken up courses/seminars/training on

\section{Table 2 Hypothesis}

\begin{tabular}{|c|c|}
\hline Hypothesis & Description \\
\hline $\mathrm{H} 1$ & Attitude towards entrepreneurship (X1) has direct effect on entrepreneurship education (Z) \\
\hline $\mathrm{H} 2$ & Subjective norms (X2) have direct effect on entrepreneurship education (Z) \\
\hline $\mathrm{H3}$ & Perceived behavioral control (X3) has direct effect on entrepreneurship education (Z) \\
\hline $\mathrm{H} 4$ & Education (Z) has direct effect on entrepreneurial intention (Y) \\
\hline H5 & Attitude towards entrepreneurship (X1) has direct effect on entrepreneurial intention (Y) \\
\hline H6 & Subjective norms (X2) have direct effect on entrepreneurial intention (Y) \\
\hline $\mathrm{H7}$ & Perceived behavioral control $(\mathrm{X} 3)$ has direct effect on entrepreneurial intention (Y) \\
\hline $\mathrm{H} 8$ & $\begin{array}{l}\text { Attitude towards entrepreneurship }(X 1) \text { has indirect effect on entrepreneurial intention }(Y) \\
\text { through entrepreneurship education }(Z)\end{array}$ \\
\hline $\mathrm{H} 9$ & $\begin{array}{l}\text { Subjective norms (X2) have indirect effect on entrepreneurial intention }(Y) \text { through } \\
\text { entrepreneurship education }(Z)\end{array}$ \\
\hline $\mathrm{H} 10$ & $\begin{array}{l}\text { Perceived behavioral control }(X 3) \text { has indirect effect on entrepreneurial intention }(Y) \text { through } \\
\text { entrepreneurship education }(Z)\end{array}$ \\
\hline
\end{tabular}


entrepreneurship. The number of respondents were 109 undergraduate students from business school in China and 110 undergraduate students from business school in Indonesia. The students were asked to fill online questionnaire. The questionnaire was first designed in English and then translated to Chinese for students in China and Bahasa Indonesia for students in Indonesia. The ages of the respondents are similar, student with range ages around 19-23 years old.

\section{Measurement of variables}

In this study; primary data obtained through interviews, carried out directly in the field using a structured research questionnaire, is divided into 5 sections: attitude toward entrepreneurship, subjective norm, perceived behaviorial controls, entrepreneurial education, and entrepreneurial intention.

Measurement of attitude towards entrepreneurship, subjective norm, and perceived behaviorial controls was adopted from Kolvereid (1997). Overall, this instrument amounted to 17items for the measurement of entrepreneurial education with 7 items adopted from Leon and Palaci Descals (2007). While entrepreneurial intention variable was measured with four items borrowed from Kolvereid (1997).

\section{Result data analysis}

\section{Assumptions test}

Testing the assumptions used in the regression is essential to ensure that the obtained regression model meets the criteria of BLUE (Best Linear Unbiased Estimated), the linear model is not biased. Normal PP plot graph shows that the distribution of the data to be around the diagonal line, and the direction of its spread in the direction diagonal (bottom left to the top), so the assumption of normal data distribution are met. The analysis showed that each independent variable has a value of variance inflation factor (VIF) which is less than 5 . Thus, it can be stated as the model-free regression multicollinearity problem (Table 3).

Validity test results using the approach corrected item-total correlations shows that all the items used in this research is valid at 0.01 level, as indicated by the value of ' $r$ ' calculated for each item was the same and greater than the critical ' $r$ ' of 0.30 . Thus, all items of empirical indicators can be used in subsequent data processing. Reliability test results, based on the value of Cronbach alpha $(\alpha)$, shows all the variables studied meet the elements of reliability with Cronbach alpha value $(\alpha)$ as it is greater than 0.60 (Sekaran 2000).

\section{Goodness of fit test}

From the results of the model goodness of fit test, it can be seen that the model was fit to the data model because there is at least one result is met requirement. More details are presented in Table 4 .

\section{Hypothesis analysis}

To test the hypothesis about the influence of direct and indirect theory of planned behavior to Entrepreneurial Intention through student education variable, path analysis technique was used by making use of existing software AMOS (Analysis of Moment 
Table 3 Validity and reliability test

\begin{tabular}{|c|c|c|c|c|c|c|c|c|c|}
\hline \multirow[t]{3}{*}{ Variable } & \multirow[t]{3}{*}{ Item } & \multicolumn{5}{|l|}{ Correlation } & \multirow{2}{*}{\multicolumn{2}{|c|}{ Alpha }} & \multirow[t]{3}{*}{ Status } \\
\hline & & \multicolumn{2}{|l|}{$R$} & \multicolumn{2}{|l|}{ Sig } & \multirow[t]{2}{*}{$\overline{\text { Status }}$} & & & \\
\hline & & Indonesia & China & Indonesia & China & & Indonesia & China & \\
\hline \multirow{3}{*}{$\begin{array}{l}\text { Attitude towards } \\
\text { entrepreneurship }\end{array}$} & $\mathrm{X} 1.1$ & 0.802 & 0.877 & 0.000 & 0.000 & Valid & 0.743 & 0.778 & Reliable \\
\hline & $X 1.2$ & 0.803 & 0.864 & 0.000 & 0.000 & Valid & & & \\
\hline & $X 1.3$ & 0.823 & 0.751 & 0.000 & 0.000 & Valid & & & \\
\hline \multirow[t]{5}{*}{ Subjective norm } & $X 2.1$ & 0.690 & 0.615 & 0.000 & 0.000 & Valid & 0.662 & 0.655 & Reliable \\
\hline & $X 2.2$ & 0.707 & 0.711 & 0.000 & 0.000 & Valid & & & \\
\hline & $\times 2.3$ & 0.669 & 0.639 & 0.000 & 0.000 & Valid & & & \\
\hline & $\times 2.4$ & 0.640 & 0.654 & 0.000 & 0.000 & Valid & & & \\
\hline & $\times 2.5$ & 0.570 & 0.618 & 0.000 & 0.000 & Valid & & & \\
\hline \multirow{7}{*}{$\begin{array}{l}\text { Perceived behavioral } \\
\text { control }\end{array}$} & $\times 3.1$ & 0.637 & 0.683 & 0.000 & 0.000 & Valid & 0.781 & 0.808 & Reliable \\
\hline & $\times 3.2$ & 0.679 & 0.357 & 0.000 & 0.000 & Valid & & & \\
\hline & $\times 3.3$ & 0.774 & 0.803 & 0.000 & 0.000 & Valid & & & \\
\hline & $\times 3.4$ & 0.659 & 0.699 & 0.000 & 0.000 & Valid & & & \\
\hline & $\times 3.5$ & 0.683 & 0.678 & 0.000 & 0.000 & Valid & & & \\
\hline & $\times 3.6$ & 0.571 & 0.837 & 0.000 & 0.000 & Valid & & & \\
\hline & $\times 3.7$ & 0.609 & 0.717 & 0.000 & 0.000 & Valid & & & \\
\hline \multirow{6}{*}{$\begin{array}{l}\text { Entrepreneurship } \\
\text { education }\end{array}$} & $\mathrm{Z} 1.1$ & 0.580 & 0.837 & 0.000 & 0.000 & Valid & 0.656 & 0.857 & Reliable \\
\hline & $\mathrm{Z} 1.2$ & 0.407 & 0.775 & 0.000 & 0.000 & Valid & & & \\
\hline & Z1.3 & 0.637 & 0.771 & 0.000 & 0.000 & Valid & & & \\
\hline & Z1.4 & 0.691 & 0.785 & 0.000 & 0.000 & Valid & & & \\
\hline & $\mathrm{Z} 1.5$ & 0.574 & 0.705 & 0.000 & 0.000 & Valid & & & \\
\hline & Z1.6 & 0.727 & 0.707 & 0.000 & 0.000 & Valid & & & \\
\hline \multirow[t]{3}{*}{ Entrepreneurial intention } & $Y 1.1$ & 0.765 & 0.893 & 0.000 & 0.000 & Valid & 0.684 & 0.881 & Reliable \\
\hline & $\mathrm{Y} 1.2$ & 0.777 & 0.926 & 0.000 & 0.000 & Valid & & & \\
\hline & $\mathrm{Y} 1.3$ & 0.813 & 0.886 & 0.000 & 0.000 & Valid & & & \\
\hline
\end{tabular}

Structure) version 18.00 . The analysis of the ten hypotheses proposed in this study is presented in Table 5.

Model of the relationship between variables is presented in Figure 3 and Figure 4 below:

Based on the results of path analysis; it can be seen that among the three independent variables (attitude toward entrepreneurship, subjective norm, perceived behaviorial control) tested against the direct impact of entrepreneurial education, Perceived behavioral control has most significant effect both to entrepreneur education or entrepreneurial intention in the case of students from China. Meanwhile in the case of students in Indonesia, attitude towards entrepreneurship alone has most significant effect to entrepreneur education (at 0.221 ) and perceived behavioral control has most significant effect to entrepreneurial intention (at 0.336).

Table 4 Goodness of fit test

\begin{tabular}{llll}
\hline Default model & Goodness model & Result & Status \\
\hline CMIN & Less $\left(<x^{2}\right.$ table $)$ & 0.000 & Fit \\
GFI & $>0.9$ & 1.000 & Fit \\
CFI & $\geq 0.095$ & 1.000 & Fit \\
\hline
\end{tabular}


Table 5 Hypothesis analysis

\begin{tabular}{|c|c|c|c|c|c|c|c|c|c|}
\hline & \multirow[t]{2}{*}{ Affect between variables } & \multicolumn{4}{|l|}{ China } & \multicolumn{4}{|c|}{ Indonesia } \\
\hline & & Affect & $t$-statistic & $P$ value & Description & Affect & $t$-statistic & $P$ value & Description \\
\hline $\mathrm{H} 1$ & Attitude towards entrepreneurship $\left(X_{1}\right) \rightarrow$ education (Z) & 0.134 & 1.409 & 0.159 & Not significant & 0.221 & 2.319 & $0.020^{*}$ & Significant \\
\hline $\mathrm{H} 2$ & Subjective norms $\left(X_{2}\right) \rightarrow$ education $(Z)$ & 0.205 & 2.022 & $0.043^{*}$ & Significant & 0.159 & 1.670 & 0.095 & Not significant \\
\hline $\mathrm{H} 3$ & Perceived behavioral control $\left(X_{3}\right) \rightarrow$ education $(Z)$ & 0.402 & 4.411 & $0.000^{* *}$ & Significant & -0.031 & -0.334 & 0.739 & Not significant \\
\hline $\mathrm{H} 4$ & Education $(\mathrm{Z}) \rightarrow$ entrepreneurial intention $(\mathrm{Y})$ & 0.201 & 2.466 & $0.014^{*}$ & Significant & -0.019 & -0.219 & 0.826 & Not significant \\
\hline H5 & Attitude towards Entrepreneurship $\left(X_{1}\right) \rightarrow$ entrepreneurial intention $(Y)$ & 0.062 & 0.768 & 0.443 & Not significant & 0.159 & 1.722 & 0.085 & Not significant \\
\hline H6 & Subjective norms $\left(X_{2}\right) \rightarrow$ entrepreneurial intention $(Y)$ & 0.111 & 1.274 & 0.203 & Not significant & 0.194 & 2.177 & $0.029^{*}$ & Significant \\
\hline $\mathrm{H7}$ & Perceived behavioral control $\left(X_{3}\right) \rightarrow$ entrepreneurial intention $(Y)$ & 0.296 & 6.101 & $0.000^{* *}$ & Significant & 0.336 & 3.907 & $0.000^{* *}$ & Significant \\
\hline H8 & Attitude towards entrepreneurship $\left(X_{1}\right) \rightarrow$ entrepreneurial intention $(Y)$ through education (Z) & 0.027 & 1.221 & 0.222 & Not significant & 0.001 & -0.225 & 0.822 & Not significant \\
\hline H9 & Subjective norms $\left(X_{2}\right) \rightarrow$ entrepreneurial intention $(Y)$ through education (Z) & 0.041 & 1.565 & 0.118 & Not significant & -0.003 & -0.224 & 0.822 & Not significant \\
\hline $\mathrm{H} 10$ & Perceived behavioral control $\left(X_{3}\right) \rightarrow$ entrepreneurial intention $(Y)$ through education (Z) & 0.081 & 2.156 & $0.031^{*}$ & Significant & -0.004 & 0.189 & 0.850 & Not significant \\
\hline
\end{tabular}




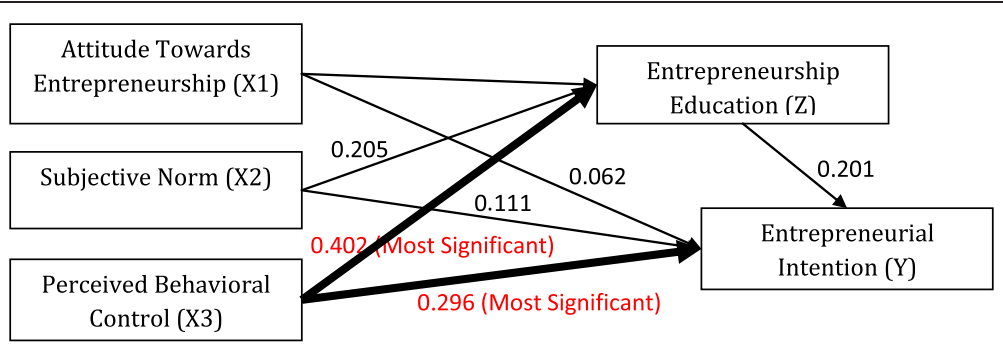

Figure 3 Relationship between variables in China sample.

After conducting tests on three variables directly influence theory of planned behavior to entrepreneurship education to students in China, found that only subjective norm (at 0.205) and perceived behavioral control (at 0.402) have significant influence on entrepreneurial education. This result supports the hypothesis $2(\mathrm{H} 2)$ and hypothesis 3 (H3). It was also found a direct effect of entrepreneurship education on entrepreneurial intentions (at 0.201 ) in which these results support the hypothesis 4 (H4). In the sample of students in China were found also influence perceived behavioral control on entrepreneurial intention (at 0.296), these results support the hypothesis 7 (H7). In addition it was also found that the effect of the indirect influence of perceived behavioral control on entrepreneurial intention (at 0.081) through entrepreneur education which these findings support the hypothesis 10 (H10).

In the sample of students in Indonesia, only one variable theory of planned behavior which has a direct influence on entrepreneurship education (at 0.221 ), providing support for hypothesis $1(\mathrm{H} 1)$. In addition it was also found that the direct effect of subjective norm (at 0.194) and perceived behavioral control (at 0.336) to the entrepreneurial intention that these results support the hypothesis 6 (H6) and hypothesis 7 (H7).

However, among Indonesian students, this study found no direct significant effect of subjective norms and perceived behavioral control on entrepreneurship education (H2 and H3), found no direct significant effect of entrepreneurship education on entrepreneurial intention ( $\mathrm{H} 4)$ and found no direct effect on attitude toward entrepreneurship on entrepreneurial intention (H5). This research also found no direct significant effect on attitude towards entrepreneurship and subjective norms to entrepreneurial education in Chinese students (H8 \& H9). It was also found that there is no direct significant effect of attitude towards entrepreneurship and entrepreneurial education on entrepreneurial intention in Indonesian students.

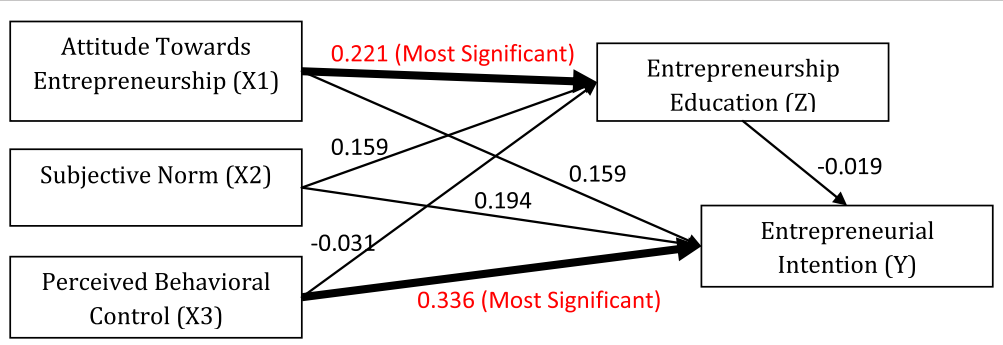

Figure 4 Relationship between variables in Indonesia sample. 
The F-test results showed significant results with $R$ square value $=0,688$ in Chinese students and $\mathrm{R}$ square value $=0,394$ in Indonesian students which means that about $68,8 \%$ of the research model is described by the variables in China and only about $39,4 \%$ of the research model is described by the variables in Indonesia. The low value of $\mathrm{R}$ allegedly caused the rejection of seven research hypotheses in this model for Indonesian students.

\section{Discussion}

Perceived behavioral control factor has the greatest influence (mist significant) both in motivating their entrepreneurship education (effect of 0.402) and raises their entrepreneurial intentions (effect of 0.296) for students in China. This means that students in China are more motivated in entrepreneurship education and have the entrepreneurial intention because they feel capable and able to face the possibility of obstacles in setting up their own business. Easy or not easy feeling in having one's own business has a significant influence on entrepreneurial education for students in China. As Mentioned in the literature review, perceived behavioral controls reflect entrepreneurial experiences in the past and anticipating the obstacles that may arise, therefore it can be concluded that students in China motivated by their undergoing entrepreneurial education because they had entrepreneurial experience in the past and want to get additional knowledge about entrepreneurship. Additional knowledge can be gained from some other fellow entrepreneurs or additional facilities and guidance from the school.

From in-depth interviews were conducted for students in China, it can be concluded that some of those who have business experience in the past with deliberately follow entrepreneurship education and training provided by the campus. Entrepreneurship education and training provided by the school usually is optional, not compulsory subjects (there are only two to three entrepreneurship courses should be taken as a compulsory subject). These students have the expectation to obtain information from the network and entrepreneurial education in following him so that their business experience in the past can be said to be one of the main factors that affect the interests of entrepreneurship. Thus it can be suggested that the university should provide practice entrepreneurship courses as a compulsory subject, the practice of entrepreneurship courses students will be conditioned to have a real entrepreneurial experience. By having a real entrepreneurship experience, is expected to lead to student entrepreneurship intentions.

While in case of students in Indonesia, attitude toward entrepreneurship factor has the highest influence (at 2,319) to motivated students entrepreneurship education. This implies that students in Indonesia are more motivated in their entrepreneurial educated because they have a view that has its own business is beneficial for them. On the other hand, factors that more affecting student in creating their entrepreneurial intentions is perceived behavioral control (at 0.336). It can be concluded that in the end, those who have entrepreneurial intentions are students who have confidence, had entrepreneurial experience, and be able to understand the obstacles that may arise in running a business.

From the results of in-depth interviews were conducted on students in Indonesia, found that they were inspired young entrepreneur figures and some local entrepreneurs 
in Indonesia, this inspired people said they have the view that entrepreneurship is something that is more advantageous compared to other professions. Advantageous in view here is that they are self-employed is the boss for themselves, besides if it has successfully gained profit is greater when compared to being an employee in a company or working in government sector. Indonesian students are motivated in entrepreneurial education because they have the view that being an entrepreneur is favorable. If someone has a view that being an entrepreneur is a profession that is more advantageous compared to other professions, then they will be motivated to give attention to the material presented by entrepreneurial education in school. Featuring profiles of successful entrepreneurs (mainly young entrepreneurs) will aid in increasing the interest of students motivated entrepreneurship education. Thus, this result has Becomes a new finding.

Perceived control behavioral has positive significant effect on entrepreneurial intention both in Chinese and Indonesian students. This indicates that students who have intention of entrepreneurship (both in China and Indonesia) are those who have entrepreneurial experience and understanding about the possible obstacles that can arise in implementing entrepreneurship. This research finding about there is significant effect of perceived behavioral control on entrepreneurial intention support the results of research and Basu and Virick (2007); Gelderen et al. (2007); Kolvereid and Isaksen (2006); Krueger et al. (2000); Autio et al. (2001); Wu and Wu (2008); Grid and Gird and Bagraim (2008). While research finding about there is significant effect of perceived behavioral control on entrepreneurship education becomes a new finding.

After testing indirect effect on students in China, it was found that perceived behaviourial control has indirect effects on entrepreneurial intention through entrepreneurial education. This imply that those who have the entrepreneurial experience and know obstacles that may arise in their business and who are also supported by entrepreneurial education have a significant effect on their entrepreneurial intention. . This result becomes the new finding.

Other finding in this study is social networks (influence of family and close friends) in China also has significantly direct effect on students to motivate their entrepreneurial education. This is in contrast to students in Indonesia, where there is no direct significant influence of social networks on them for motivated their entrepreneurial education. This show that compared to students in Indonesia, students in China considered the opinion of the family and the close friends more carefully, so as to motivate those who are undergoing entrepreneurship education in school. This result becomes a new finding.

Entrepreneurial education in students in China has a direct significant effect on entrepreneurial intentions, while it has no direct significant effect in the students in Indonesia. This implies that when compared with Indonesia, entrepreneurial education in China prepare students more to become entrepreneurs as they have better facility that can provide support to start a business and provide practical knowledge of entrepreneurship. There is an absence of direct influence of education on entrepreneurial intention in Indonesian students, possibly because the students feel that entreprenurial education in Indonesia is too theoretical due to which students find it difficult to apply the knowledge they have on entrepreneurship. University of Indonesia does not provide assistance or access for students to start a business. This is in contrast with the 
entrepreneurship program is given to students Hohai university, in addition to the conditions in china which supports students to start a business, the university also provides assistance for students who want to start a business, even some of the lecturers also provide business networking information to students. This finding supports the research of Basu \& Virick (2007); Leon and Palaci Descals (2007); and Karali (2013).

Attitude of students in China and Indonesia towards entrepreneurship does not have a significantly direct effect on entrepreneurial intentions; although students share a view that there are lot of benefits in entrepreneurship, it is not enough to influence the students to have entrepreneurial intention. Social Network has no direct significant effect to make students in China have entrepreneurial intention. This becomes an interesting finding given the social network has a significant effect on students in China to select entrepreneurial education. It indicates that even though the opinion of their closest has an important role in motivating their entrepreneurial education, it does not mean that the opinion of the people closest to them can have influence on their desire to become an entrepreneur. It also indicates that the force of the family and close friends cannot motivate students to be an entrepreneur.

While in the case of students in Indonesia, entrepreneurial intention is determined by the support from family and support of people who are considered influential. This usually happens when they see that the people closest to them are successful in running their own business and give them some practical knowledge about their business. Therefore, to encourage students to have entrepreneurship intentions, the support of the family and closest friends is required. These findings support the results of research and Basu and Virick (2007), Galderen et al. (2007); Kolvereid \& Isaksen (2006), and Gird \& Bagraim (2008). Another hypothesis related to indirect effect is not proven in this study.

\section{Conclusion}

The study found indirect effect on perceived behavioral controls to entrepreneurial intention with entrepreneurial education as an intervening variable. In addition to the other findings in this study it can be concluded:

1. In China Students, perceived behavioral control is a variable has the most significant effect in explaining the influence of theory of planned of behavior both on entrepreneurial education and entrepreneurial intention in China students. Thus it can be suggested that the university should provide practice entrepreneurship courses as a compulsory subject, the practice of entrepreneurship courses students will be conditioned to have a real entrepreneurial experience. By having a real entrepreneurship experience, is expected to lead to student entrepreneurship intentions.

2. In Indonesia students, perceived behavioral control is a variable that has the most significant effect on entrepreneurial intention. While the attitude toward entrepreneurship are also factors that have the most significant influence on entrepreneurship education. Featuring profiles of successful entrepreneurs (mainly young entrepreneurs) will aid in increasing the interest of students motivated entrepreneurship education.

3. This research found an indirect effect of perceived behavioral control on entrepreneurial intention through entrepreneurship education to students in China. 
This imply that those who have the entrepreneurial experience and know obstacles that may arise in their business and who are also supported by entrepreneurial education have a significant effect on their entrepreneurial intention.

\section{Implications for future research}

This research was focused on examining the influence of theory of planned behavior to predict entrepreneurial intention and not paying much attention to predict entrepreneurial behavior. Thus, further research is expected to explain the subject of entrepreneurial behavior. In addition, this study was focused on the theory of planned behavior in explaining entrepreneurial intentions of students in starting new business. In addition, variables related to entrepreneurship education, this study does not explain the intentions of the students before and after attending entrepreneurship education; this study only describes the condition of the students' intentions after take entrepreneurship education in campus. Thus further research is better able to compare how the theory of planned behavior to influence entrepreneurial intentions after and before entrepreneurship education.

Competing interests

The authors declare that they have no competing interests.

\section{Authors' contributions}

YK: participated in its design, coordination, and critical revision. PIS: participated in its design of the study, conceived of the study, collecting the data, and performed the statistical analysis. All authors read and approved the final manuscript.

\section{Author details}

${ }^{1}$ Economic and International Trade, Hohai University, 8 West Focheng Road, Nanjing Jiangsu 210098, China. ${ }^{2}$ School of Business, Hohai University, 1st Xikang Road, Nanjing Jiangsu 210098, China.

Received: 29 July 2014 Accepted: 21 October 2014

Published online: 27 January 2015

\section{References}

Ajzen, I. (1991). The theory of planned behavior. Organizational Behavior and Human Decision Processes, 50(2), $179-211$.

Ajzen, I. (2001). Nature and operation of attitudes. Annual Review of Psychology, 52, 27-58.

Anonim. (2013). Employment Rate of University Graduates in China 2013 (Fee-based). http://www.statista.com/statistics/ 280947/employment-rate-of-university-graduates-in-china/ (accessed 12 June 2014).

Autio, E, Keeley, RH, Klofsten, M, Parker, GGC, \& Hay, M. (2001). Entrepreneurial intent among students in Scandinavia and in the USA. Enterprise and Innovation Management Studies, 2(2), 145-160.

Basu, A, \& Virick, M. (2007). Assesing entrepreneurial intentios among students: a comparative study. In Peer-reviewed papers, $71-86$.

Binks, M, Starkey, K, \& Mahon, C. (2006). Entrepreneurship education and the business school. Technology Analysis and Strategic Management, 18(1), 1-18.

Bird, B. (1988). Implementing entrepreneurial ideas: the case for intention. Academy of Management Review, 13(3), $442-453$

Clayton, G. (1989). Entrepreneurial Education at the Postsecondary Level. Ontario Bay: Report for Confederation College of Applied Arts and Sciences.

Fayolle, AG, \& Gailly, B. (2005). Using the theory of planned behaviour to assess entrepreneurship teaching programmes. In Centre for Research in Change, Innovation and Strategy: 1-18.

Fishbein \& Ajzen 1985 in Tjahjono \& Ardi. (2008). Management students' intention to be an entrepreneur. Utilitas Jurnal Manajemen dan Bisnis, 16(1), 46-63.

Fleming, P. (1996). Entrepreneurship education in Ireland: a longitudinal study. Academy of Entrepreneurship Journal, 2 (1), 95-119.

Gelderen, B, Pragg, MV, Bodewes, P, \& Gils, AV. (2007). Explaining entrepreneurial intentions by means of the theory of planned behavior. Journal of Career Development International., 13(6), 2008.

Gird, A, \& Bagraim, J. (2008). The theory of planned behavior as predictor of entrepreneurial intent amongst final-year university students. South African Journal of Psychology, 38(4), 711-724.

Ismail, M, Khalid, SA, Othman, M, Rahman, NA, Kassim, KM, \& Zain, RS. (2009). Entrepreneurial intention among Malaysian Undergraduates. International Journal of Business and Management, 4, 10. Oktober 2009.

Jenkins, M, \& Johnson, G. (1997). Entrepreneurial intentions and outcomes: a comparative causal mapping study. Journal of Management Studies, 34(6), 895-920.

Karali, S. (2013). The Impact of Entrepreneurship Education Program on Entrepreneurial Intention: An Application of The Theory of Planned Behavior. (Unpublished master's thesis). Rotterdam, Netherlands: Erasmus School of Economics. 
Keat, OY, Selvarajah, C, \& Meyer, D. (2011). Inclination towards entrepreneurship among university students: an empirical study of malaysian university students. International Journal of Business and Siocial Science, 2, 4. March 2011

Kolvereid, L. (1997). Prediction of employment status choice intentions. Entrepreneurship: Theory \& Practice, 21(1), 47-57.

Kolvereid, L, \& Isaksen, E. (2006). New business start-up and subsequent entry into self-employment. Journal of Business Venturing, 21(6), 866-885.

Krueger, NF, Jr, \& Carsrud, AL. (1993). Entrepreneurial intentions: applying the theory of planned behaviour. Entrepreneurship \& Regional Development, 5(4), 315-330.

Krueger, NF, Jr, Reilly, MD, \& Carsrud, AL. (2000). Competing models of entrepreneurial intentions. Journal of Business Venturing, 15, 411-432

Kuratko, DF. (2005). The Emergence of Entrepreneurship Education: Development, Trends, and Challenges. Entrepreneurship Theory and Practice, 29(5), 577-598.

Leon, JAM, \& Palaci Descals, FJ. (2007). The psycosocial profile of the university entrepreneur. Psychology in Spain, 11(1), $72-84$

Liñán, F, \& Chen, YW. (2009). Development and cross-cultural application of a specific instrument to measure entrepreneurial intentions. Entrepreneurship: Theory \& Practice, 33(3), 593-617.

Maguire, M, \& Lunati, M. (2009). Evaluation of programmes concerning education for entrepreneurship.

Sciascia, S, Alberti, F, \& Poli, A. (2004). Entrepreneurship education: note on an ongoing debate (14th Annual IntEnt Conference). Italy: University of Napoli Federico.

Sekaran, U. (2000). Research methods for business, a akill-building approach. America: Thirt Edition, John Wiley \& Sons, Inc.

Selcuk, SS, \& Turker, D. (2009). Which factors affect entrepreneurial intention of university students. Journal of European Industrial Training, 3(2), 142-159.

Summer, \& David, F. (1998). An empirical investigationof personal and situational factors that relate to the formation of entrepreneurial intention (Doctoral dissertation, University of North Texas). Ann Arbor, MI: UMI Desertation Srevices.

Sutianto, FD. (2012). Kasihan Ada 493.000 Sarjana Mengangur di Indonesia. Access from http://finance.detik.com/read/ 2012/07/05/122510/1958279/4/.

Wu, S, \& Wu, L. (2008). The impact of higher education on entrepreneurial intention of university student in China. Journal of Small Bussiness and Entrerprise Development, 15, 4.

Yanhong, J, \& Yibin, L. (2011). The orientation of entrepreneurship education of China's universities in the context of sustainable development.

Zimmerer, WT. (2002). Essentials of entrepreneurship and small business management (3rd ed.). New York: Prentice-Hall.

Submit your manuscript to a SpringerOpen ${ }^{\circ}$ journal and benefit from:

- Convenient online submission

- Rigorous peer review

- Immediate publication on acceptance

- Open access: articles freely available online

- High visibility within the field

- Retaining the copyright to your article

Submit your next manuscript at $>$ springeropen.com 